\title{
Disaster Risk Reduction through school learners' awareness and preparedness
}

\begin{tabular}{|c|}
\hline $\begin{array}{l}\text { Authors: } \\
\text { Takalani S. Rambau }{ }^{1} \\
\text { Lukas D. Beukes }^{2} \\
\text { William Fraser }\end{array}$ \\
\hline $\begin{array}{l}\text { Affiliations: } \\
{ }^{1} \text { Department of Curriculum } \\
\text { and Instructional Design and } \\
\text { Development, University of } \\
\text { Pretoria, South Africa }\end{array}$ \\
\hline $\begin{array}{l}{ }^{2} \text { Department of Humanities, } \\
\text { University of Pretoria, } \\
\text { South Africa }\end{array}$ \\
\hline $\begin{array}{l}{ }^{3} \text { Department of Science, } \\
\text { Mathematics and Technology } \\
\text { Education, University of } \\
\text { Pretoria, South Africa }\end{array}$ \\
\hline $\begin{array}{l}\text { Correspondence to: } \\
\text { Takalani Rambau }\end{array}$ \\
\hline $\begin{array}{l}\text { Email: } \\
\text { strambau@gmail.com }\end{array}$ \\
\hline $\begin{array}{l}\text { Postal address: } \\
\text { PO Box } 72135 \text {, Lynnwood } \\
\text { Ridge } 0040, \text { South Africa }\end{array}$ \\
\hline $\begin{array}{l}\text { Key Words: } \\
\text { Curriculum; Disasters; } \\
\text { Hazards; Vulnerability; } \\
\text { Disaster education }\end{array}$ \\
\hline $\begin{array}{l}\text { Dates: } \\
\text { Received: } 28 \text { July } 2011 \\
\text { Accepted: } 14 \text { Aug. } 2012 \\
\text { Published: } 01 \text { Nov. } 2012\end{array}$ \\
\hline $\begin{array}{l}\text { How to cite this article: } \\
\text { Rambau, T.S., Beukes, L.D., } \\
\text { Fraser, W., 2012, 'Disaster } \\
\text { Risk Reduction through } \\
\text { school learners' awareness } \\
\text { and preparedness', Jàmbá: } \\
\text { Journal of Disaster Risk } \\
\text { Studies 4(1), Art. \#61, } \\
11 \text { pages. http://dx.doi. } \\
\text { org/10.4102/jamba.v4i1.61 }\end{array}$ \\
\hline
\end{tabular}

(C) 2012. The Authors Licensee: AOSIS OpenJournals. This work is licensed under the Creative Commons Attribution License.
In 2006, the ISDR (International Strategy for Disaster Reduction) (2007) initiated a campaign called Disaster Risk Reduction Begins at School to encourage the integration of disaster risk education into school curricula in countries vulnerable to disasters. A study was initiated to determine how education, in particular curriculum development and teaching, contributes to South African learners' hazard awareness and disaster preparedness. Mixed method research (consisting of questionnaires, interviews and document reviews) was done to collect data. 150 educators from Gauteng, the Western Cape, KwaZulu-Natal, North West and the Eastern Cape completed questionnaires. Five curriculum coordinators, three disaster specialists and two disaster lecturers were interviewed to record their perspectives. The first finding of the study was that the majority of educators, disaster specialists and curriculum coordinators identified floods, fire, droughts, epidemics, road accidents and storms as the most prevalent disasters in the country. The second finding from the literature and empirical data collection revealed that South African communities, particularly people residing in informal settlements and other poor areas, are more vulnerable to disasters than their counterparts in more affluent areas. The third finding of the study was that teaching learners about hazards and disasters is vital and must be expanded.

\section{Introduction}

This article reports the results of an investigation to determine how education, and the curriculum and teaching in particular, could enhance learners' hazard awareness and disaster preparedness. The article focuses on three concerns: the hazards that are prevalent in South Africa, the extent to which South African communities are vulnerable to disasters and the extent to which schools in South Africa teach about hazards and disasters. This article discusses some results of our investigation into these matters and also some of the implications of these results.

\section{Background}

The global community is experiencing an increasing number of disasters that range from earthquakes, floods, storms, epidemics, fires, landslides, hurricanes, tsunamis and social conflicts, all of which may result in loss of life and property. South Africa, just like any other country, experiences its share of disasters such as seasonal floods, fires, road and rail accidents, droughts, sinkholes and epidemics; and these are usually compounded by the prevalence of informal settlements, a lack of proper planning during construction and a lack of political will.

From his experience of the Wujal Wujal aboriginal community in the Cape York Peninsula which was hit by Cyclone Rona, King (2000) noted that despite advances in communication technology, remote communities occasionally still failed to receive any warning at all, as transmitters failed or remote area broadcasts were made from very distant locations where there was no knowledge of local conditions. Rao (2007) also maintained that warning signals were not taken seriously, as evidenced by events in December 2004 when people ignored warnings about the possibility of dangerous waves:

Everyone on the beach like everywhere else in many countries around the Indian Ocean followed seaward to a point of no return, curiously watching the unusually receding tide, in a false-ebb which normally precedes a tsunami. (p. 9)

This is an indication that sometimes people do not take seriously whatever warnings they do get before a disaster strikes.

Whilst disaster relief has been at the forefront for quite a long time, communities are increasingly looking at disaster risk reduction as the best solution to safeguard human lives and property. Scholars and policy makers are relying on disaster preparedness and resilience as strategies to ensure disaster risk reduction whilst the International Strategy for Disaster Reduction (ISDR) 
(2007) has indicated that disaster management education is vital if school children's are to be prepared and resilient in the face of disasters. According to the UNESCO DirectorGeneral, Koichiro Matsuura (UNESCO 2007), anticipating, educating and informing are important ways to reduce the risk as well as the deadly effect of disasters.

In recognition of the role that education should play in disaster risk reduction, the International Strategy for Disaster Reduction dedicated 2006 as a year for encouraging both the integration of disaster risk education in school curricula in countries vulnerable to natural hazards and the safe construction and renovation of school buildings to withstand natural hazards. Their campaign, called Disaster Risk Reduction Begins at School, was inaugurated in many countries, including South Africa. The National Disaster Management Framework (NMDF), introduced in South Africa in 2005, also made provision for disaster risk education to be included in the national curriculum.

Because South Africa as part of the global community is affected by the increase in the frequency of disasters and because education is the primary means of developing awareness and resilience, it was essential to determine how the South African education system contributed to learners' awareness of hazards and to their resilience in the face of disasters. This article has taken into cognition that the education system is broad and has many components, hence the focus is limited to the role of the national curriculum and teaching.

It should also be noted that a report of the study commissioned by the National Disaster Management Centre (NMDC) (2010) revealed that:

An analysis of the National Curriculum Statement directives shows a convincing alignment - in especially learning outcome 3 in Social Sciences (Geography) at Grade 7 - with the disaster risk management concepts and principles contained in South Africa's National Disaster Management Framework of 2005. Children will have a basic understanding and knowledge of disaster risk management concepts and principles if these curriculum directives are implemented in a skilful and creative manner in the classroom [...] Furthermore, the basis laid at primary school level is continued in secondary school curricula. However, the inclusion of disaster risk management concepts and principles are limited to a few learning areas (specifically Geography) and Grades (Grade 12: Life Orientation). Disaster risk management education is therefore not reaching all senior secondary school children, because of learning area choices and high secondary school dropout rates. The lack of focus on cultivating disaster risk reduction behaviour is to be found in a lack of proper guidance and support to schools. (pp. 12-13)

As will be seen from the discussions in the sections that follow, some scholars are of the view that education plays a critical role in enhancing learners' disaster awareness and preparedness. The next section discusses the research method applied in the investigation.

\section{Research methodology}

The arguments advanced in this article rely on data collected through a mixed method research approach combining questionnaires, interviews, literature and policy documents review. 150 educators teaching in schools located in informal settlements in Gauteng, the Western Cape, KwaZulu-Natal, North West and the Eastern Cape completed questionnaires. Schools in Ivory Park, Khayelitsha, Isipingo, Brits and Bizana were especially selected as it was convenient to access educators in these settlements. The ten interview participants were selected because of their availability and their responses to an invitation sent to provincial departments. The interview participants were five curriculum coordinators, three disaster specialists and two disaster lecturers. Policy documents and scholarly articles were reviewed to determine what had been recorded on the phenomena being studied.

A convenience and purposeful sampling of participants was used to select interview participants and questionnaire respondents. Firstly, permission to conduct research in schools located in all nine provinces was requested and gained. The interview data collection was meant to compensate for those provinces that did not respond to the questionnaires. Only one province, Limpopo, did not participate as permission to collect data was not granted. There was no response to the questionnaires and the curriculum coordinator in the area was not available to participate. The five curriculum coordinators were from Mpumalanga, the Northern Cape, the Eastern Cape, Gauteng and the National Department of Basic Education. The disaster lecturers were from the Free State and Gauteng whilst the disaster specialists were from Gauteng, North West and the National Disaster Management Centre.

The rationale for selecting the interview research participants was that since they were involved in the development, implementation and review of the national curriculum, they would be able to provide insightful data on the interface of curriculum and hazards and disaster education. The 150 educators were selected because of their involvement in teaching learners and it was thought that they would therefore be able to provide insightful data on whether learners were taught about hazards and disasters. The selection of purposeful and convenience sampling was done to ensure that relevant data would be collected in spite of time and financial constraints. Even though there were constraints, the data collected were representative as $88.8 \%$ of the nine provinces were part of the research population. The literature data collection also helped by showing that communities mostly affected by disaster are poor communities in general and in particular those that reside in informal settlements. Whilst Limpopo has vast rural communities and has experienced disasters such as storms, heavy rains and veld fires, their situation is not much different from that in the Eastern Cape, North West and KwaZulu-Natal and one could argue that data collected in those three provinces would be representative of the situation in Limpopo. 
Although the study focused on learners' disaster awareness and preparedness, data were not directly collected from learners. It should be emphasised that the aim of the study was not to determine the impact of including hazards and disasters learning outcomes in the curriculum and school teaching, but to determine how curriculum and classroom teaching contribute to learners' awareness of hazards and their disaster preparedness. The purpose was therefore to look at planning and implementation with the aim of dedicating an entire study to the impact of integrating hazard and disaster teaching in the school curriculum. Another reason for not collecting data directly from learners was that a review of policy documents made it clear that the National Curriculum Statements explicitly stipulates hazard and disaster education for Grade 7 only, whilst it lists concepts such as environment, deforestation or epidemics for other grades, thereby leaving room for educators to decide whether to teach about disasters or not. Hence the data collection for this study focused on educators, curriculum and disaster experts. The limitation of not collecting data from learners was noted and is listed as an area for further investigation.

\section{Discussion of the study}

It was pointed out in the introduction that the study focused on three concerns, and the following sections discuss findings from data collected regarding the three questions raised.

\section{Concern 1: What disasters are prevalent in South Africa?}

The first concern of the study was to determine what hazards were prevalent in South Africa. The point of departure for addressing this first concern was to review the literature to determine what disasters affect the global community. Alexander (1997) defines a disaster as a rapid, sustained or profound impact of the geophysical world upon human lives and their socio-economic means of support. A related concept, hazards, has also been the subject of scholarly debate; it is closely related to the concept of disaster as the two go hand in hand and are used as such in this study. SabatesWheeler et al. (2008) define hazards as events which, if they materialise, can adversely affect a community's well-being. The argument emanating from this definition of hazards is that the difference between a disaster and a hazard is that communities can learn to live with the latter as long as they are well prepared and are able to prevent it from resulting in the loss of lives and properties. Out of various sources consulted the most interesting information came from Shaluf (2007) who gave an overview of all possible disasters that can be encountered. He included natural, human-induced and hybrid disasters, as well as a combination of natural and human-induced disasters. The schematic representation below show the disasters he identified.

The disasters identified by Shaluf (2007) and reflected in figure 1 are supported by Paton (2003), Paton and Johnston (2001) and Alexander (1997) who maintain that disasters can be either human-made or natural occurrences; either way they have a devastating effect on human lives and their means of existence. Hemingway (2004), Berriman (2004), Gey van Pittius, Sampson, Warren and Van Helden (2004), Kana and Mizrahi (2005), Boshoff, Barry III and Mizrahi (2004), Martin and Williamson (2004), Hargrove (2008:53), Gregson, Waddel and Chandiwana (2001) and Martin (2005) focus on diseases such as malaria, tuberculosis and AIDS which can be categorised under biological disasters in Shaluf's disaster tree.

Shaluf's disaster tree (2007) was also used to analyse the South African situation in order to determine which disasters were prevalent. It appeared that most of the information on disasters in South Africa had been recorded by the National Disaster Management Framework and related publications. Scholars such as Reid and Vogel (2006), Tempelhoff et al. (2009), Napier and Rubin (2002), Mgquba and Vogel (2004), Holloway and Roomaney (2008) and Meiklejohn and Sumner (2005) concur that South Africa is dominated by localised incidents such as wildfires, seasonal flooding and droughts.

Mulegeta et al. (2007) identified human-induced disasters such as air and water pollution, gas flaring and small scale mining accidents, toxic waste disposal, land degradation, conflict related hazards and climate change as the most prevalent disasters within sub-Saharan Africa. The National Disaster Management Framework introduced by NMDC (2005) reported that South Africa is exposed to a wide range of hazards such as droughts, cyclones, severe storms, severe floods and wildfires, and further pointed out that large numbers of people live in conditions of chronic disaster vulnerability in underserved, ecologically fragile or marginal areas.

As indicated above, ten participants, consisting of disaster lectures, specialists and curriculum coordinators, were interviewed and asked to identify disasters that were prevalent in South Africa. The participants identified numerous hazards prevalent in South Africa.

An interesting point to note is that the interview participants identified a variety of disasters in no particular order, with floods and fires being identified by all participants and droughts taking second spot (it was identified by six participants). Storms, accidents, xenophobia and epidemics were mentioned by more than one participant whilst disasters such as fog, lightning, cold weather and sinkholes were each identified by one participant only.

Another interesting discovery was that the literature review as well as some of the questionnaire respondents and interview participants identified epidemics such as AIDS, tuberculosis, bird flu, cholera and malaria as hazards. Epidemics form part of the overview given by Shaluf (2007) and scholars such as Martin and Williamson (2004), Hargrove (2008), Gregson et al. (2001), Mgquba and Vogel (2004), Napier and Rubin (2002) and Reid and Vogel (2006) have identified AIDS as an epidemic needing attention. It is important to note that 


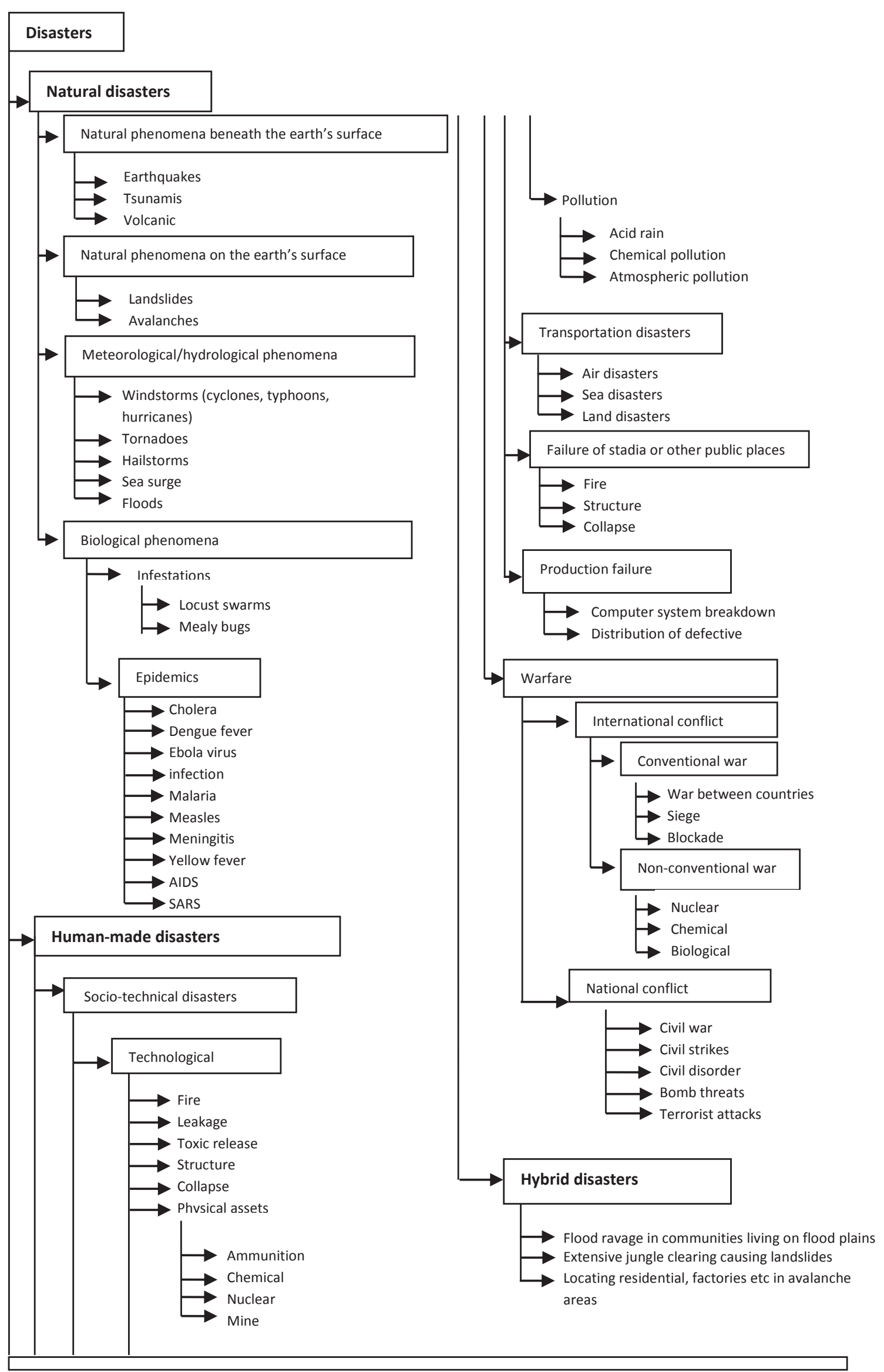


although epidemics and in particular AIDS are categorised as hazards that can lead to disasters, there are programmes specifically designed by the Department of Health and other institutions with vested interests to address these issues. There is, however, a need to review how these programmes are being understood by learners and how they affect learners' behaviour. A disaster lecturer and two curriculum coordinators commented that epidemics should form part of disaster education. This idea was also supported by one of the disaster specialists who indicated that children should be made aware of the danger of not regularly washing their hands. Two of the educator respondents mentioned HIV and AIDS in their comments about the disasters affecting their area.

Landslides, earthquakes, volcanoes or tsunamis are widely reported as common and major disasters in the world. These disasters do feature in South African literature but were not mentioned by interview respondents as disasters that affect South Africa. This observation about earthquakes, volcanoes and tsunamis is supported by a number of scholars, amongst whom are Meiklejohn and Sumner (2005), who maintain that South Africa has a relatively steep coast and should not experience as much devastation caused by earthquakes and tsunamis as is recorded in other countries. However, it is also important to note that South Africans should not live with the comfortable feeling that major disasters that have been experienced in other countries will not happen here. It is important to heed the warning of Frost-Killian (2008) that:

As we go about our daily business, the solid Earth seems safe enough, but there's far more going on beneath the surface than meets the eye. Things can change in a devastating flash through floods, earthquakes and other disasters that displace or kill the whole communities of people. The more we understand the natural forces that control the familiar landscapes of water, rocks and soils the better we can calculate - and minimise - the risks to people and property. (p. 28)

As for the questionnaire respondents, data were collected from 150 participants. They were asked whether South Africa was likely to be affected by disasters and were then given an opportunity to make comments. The chart below depicts their responses to the question.

From the educators' responses to the question of the likelihood of disasters occurring in South Africa, it was seen that $100 \%$ of the sampled educators in Gauteng and Northwest, 96.6\% in Western Cape and 86.6\% in KwaZuluNatal were certain that there was such a likelihood in the country. The information is significant because it shows the prevalence of disasters, especially if one considers the comments made by these educators. Fifteen respondents gave additional comments related to sub-question 1, six of whom were in the Western Cape, five in the Eastern Cape, two in Gauteng, one in KZN and one in North West. Some of the comments are given below.

A 32-year old male educator for Grade 7 from Gauteng commented that: 'Our school is situated in an underdeveloped area consisting of narrow roads, houses get burned by fires and floods are problematic in the area.'

An Eastern Cape female educator who has been teaching for thirteen years commented that: 'One of the local schools was recently blown away by wind storms and there have been some houses which burned from fire.'

From North West, a female respondent who has been teaching for 18 years in Brits informal settlement school commented that: 'I teach learners about road accident, floods, fire, heavy rains, wind, storms, tornadoes and droughts.'

Other educators in KwaZulu-Natal and the Western Cape also commented on disasters prevalent in those areas. Other comments identified fires, floods, storms, medical waste and accidents as hazards likely to cause disasters.

From the comments made by questionnaire respondents, interview participants and scholars, it can be concluded that South Africa is affected or likely to be affected by hazards such as floods, fires (forest and shack fires), droughts, industrial accidents and epidemics. According to the respondents the country experiences critical problems that are the result of epidemics such as AIDS, tuberculosis, rift valley fever, avian flu and foot and mouth disease, and of social conflicts such as xenophobic attacks and national strikes. According to them the country also suffers from fog, extremely cold weather and heat waves.

\section{Concern 2: To what extent are South African communities vulnerable to disasters?}

The second concern of the study was to determine the extent to which South African communities are vulnerable to disasters. When disasters occur somewhere in the world, people everywhere are inclined to reflect on their own situation and wonder whether they are vulnerable to the same fate, and Reich (2006) observes that shocking disasters can cause people to worry about society's disaster risk reduction planning and execution as a way to address the vulnerability factor. Paton and Johnston (2001) maintain that vulnerability is essential in understanding disasters in terms of preparedness, response and recovery and that it

TABLE 1: Chart displaying educators' responses on the likelihood of disasters occurring in South Africa.

\begin{tabular}{|c|c|c|c|c|c|}
\hline \multirow[t]{2}{*}{ Likelihood } & \multicolumn{5}{|c|}{ Province } \\
\hline & Gauteng & North-West & Kwa-Zulu Natal & Eastern Cape & Western Cape \\
\hline Likely & 30 & 30 & 28 & 29 & 26 \\
\hline Not likely & 0 & 0 & 2 & 1 & 4 \\
\hline
\end{tabular}

Source: Rambau, S.T., 2011, 'Educational perspectives on learner awareness of hazards and disasters', PhD thesis, University of Pretoria, Pretoria, viewed 20 August 2012, from http://upetd.up.ac. za/thesis/available/etd-10112011-121840 
can be defined in terms of demographic, socio-economic and environmental circumstances.

Whilst it is acknowledged that disasters affect communities indiscriminately, evidence has surfaced from scholars such as Reid and Vogel (2006), Mgquba and Vogel (2004), Holloway and Roomaney (2008), and Napier and Rubin (2002) that communities residing in informal settlements are more vulnerable and suffer greater losses than their counterparts in established settlements. It is important to note an observation made by Gaillard (2007) that vulnerability reflects the daily conditions of society and that hazards should be viewed as the extension of everyday hardships that occur when the victims had been marginalised geographically, socially and politically. They live in hazard-prone areas because they are poor and their voice is disregarded. Schilderman (2004) supports this idea by stating that natural disasters are on the increase not so much because natural hazards are increasing in number but because poor people are becoming more vulnerable.

Fothergill and Peek (2004) observe that poor people around the world suffer the greatest disaster losses and have the most limited access to public and private recovery assets, both in developing societies as well as in wealthy, indistrialised nations. In a South African context, it is important to note the views of scholars such as Tempelhoff et al. (2009) who report that since the second half of the 1980s South Africa's urban landscape has been characterised by the prevalence of informal settlements on the periphery of the country's towns and cities. Napier and Rubin (2002) concur that the lack of properly constructed houses and the dangerous location of informal settlements mean that when disaster strikes, informal settlement dwellers are not able to shoulder the destructive forces of floods, fire and storms. Bull-Kamanga et al. (2003) argue that urban specialists are increasingly recognising the considerable health burden that most low-income urban dwellers face from everyday hazards because of inadequate provision of water, sanitation and drainage, poor quality and overcrowded housing and poor management of pollution and road traffic.

The resource-poor communities such as those residing in informal settlements in many parts of South Africa currently live with a range of stresses and risks made worse by climatic risks, the risk of HIV infection and access to insecure land. From personal observation, these informal settlements, commonly known as squatter settlements in South Africa, are populated by poverty-stricken communities. The settlements contain many risk factors which make people residing in those areas vulnerable to disasters. The areas have often been abandoned by municipalities because they are located near streams of water, sink holes, high voltage electric poles and dumping grounds for industrial waste. Inhabitants of these settlements usually construct their shacks close to one another because of limited space and they use discarded plastic and wooden materials which are highly flammable and not strong enough to withstand heavy rains and flash floods. All these features of squatter settlements represent what can be labelled as multiple hazards and if one considers Gupta and Sharma's (2004) observation that poor, vulnerable communities suffer the multiple effects and unfathomable hardships during disasters, then it can be said that informal settlements are without doubt the most disaster-prone areas in South Africa. In most instances, those settlements are located in what is called 'no man's land', mainly because the land is not approved for human settlement and does not have a lawful private owner who is able to embark on forced removals.

These settlements are convenient for the squatters because they are often situated close to city centres and the workplace. The danger of these settlements is that when a disaster strikes, there are more fatalities because they are inaccessible to rescue officials. Now and then the media report flash floods and outbreaks of shack fires affecting South African informal settlements as well as storms affecting South African communities at large.

The argument of informal settlements being vulnerable to disasters is supported by scholars as well as media reports; one example is the following story told by a resident of an informal settlement in the Western Cape who had observed the vicious circle experienced by residents of informal settlements (Holloway \& Roomaney 2008):

Thabo watched the young man as he carried another sheet of corrugated iron down towards the river. Almost every day now, someone new was building a house in New Situ. He could still remember when there were only a few houses there. Things had been better then: there was more space, and people built their houses away from the river. Now, more and more people seemed to be arriving from the Eastern Cape, hoping to find jobs. There was no more space, but New Situ was close to the factories and other work opportunities in the towns nearby, and people kept coming in. The new ones didn't want to listen when he told them that it was unsafe to build by the river. They told him that such a small river would not cause trouble. They told him that he just wanted to prevent them joining the settlement. But they would see he was right in winter, when the river swelled with rain water. Every year, the houses by the river got flooded - sometimes they even got washed away. The people never stayed long after that, but always there were new people coming in to take their place. He wondered as he watched his little granddaughter chasing a chicken: how many more people would suffer this winter? (n.p.)

There are schools in these informal settlements and one wonders whether education in that context takes into consideration the dangers that may lie in wait for the learners.

According to Hassanian (2006), children and youth are the part of the population that are most severely affected by disasters, as they can easily panic and become difficult to manage during emergencies or crises, especially when a school or a house catches fire. According to the NMDC (2010):

There are schools in South Africa that are situated in disaster prone areas. The National Education Infrastructure Management System (NEIMS) indicates that nearly 15 per cent of all learners 
in South Africa are taught in environments that expose them to danger and to potential health hazards. Furthermore, at least 1166 (4.7 per cent) of all schools in the country are at the risk of flooding. Data on risks that pose a threat to school infrastructure and people collected through the NEIMS is an invaluable source of information for risk profiling and disaster risk reduction planning. (p. 11)

Because of this observation by the researchers our investigation focused on the most vulnerable communities, that is, people living in informal settlements. Even though the focus was on poor communities, it is important to note that all South African citizens are vulnerable to disasters but that poor people are usually the most affected by disasters.

Analysis of data from interview participants shows that South African communities are vulnerable to floods, fires, storms, epidemics and accidents (chemical and transport). Even though these disasters affect South Africa only on a limited scale, they nevertheless result in the loss of lives, property and livelihood and therefore warrant attention. The most important aspect to note here is that in other parts of the world where disasters such as earthquakes, volcanoes, landslides and bombs are experienced, the education system is used to address the problem. Classroom teaching, for example, is adapted so that teachers can focus on preparedness and appropriate responses to the catastrophes.

The figure below depicts the results from the responses of 150 educators who answered the question whether South African communities were vulnerable to disasters.

The chart above shows that all the sampled educators in Gauteng, North West and the Eastern Cape (100\%) and 97\% of those in KwaZulu-Natal and the Western Cape agree that South African communities are vulnerable to disasters. Only two educators felt that their communities were not vulnerable to disasters.

When data on the vulnerability of communities are analysed, the question arises as to what the literature says about responding to this vulnerability. Rautela (2005) is of the notion that developing local knowledge is important in disaster resilience and describes, as an example, how buildings in the Kumaoni region survive many earthquakes because of their earthquake-resistant structural design, even though they are situated in earthquake prone areas. If the people had not used those designs, developed locally, their buildings would have been razed to the ground. Shaw, Shiwaku, Kobayashi and Kobayashi (2004) stress that disaster resilience can be attained if communities have a shared vision of gathering knowledge about hazards in their area, developing the awareness that disasters can occur at any time and deepening their understanding of ways to respond in the event of a disaster.

Paton and Johnston (2001) maintain that traditional approaches should be integrated into hazard education programmes to increase resilience. Shaw et al. (2004) maintain that it is widely acknowledged that schools play an important role in awareness amongst students, teachers and parents because the more a child is aware of hazards and realistic risks, the more potential there is for the adults to be educated through the child sharing that knowledge at home.

King (2000) observes that by raising awareness of expected hazards and increasing both knowledge of and active participation in appropriate preparations, it can be hoped that people will respond more effectively to warnings and behave safely when a disaster does occur.

The literature also describes how national governments changed their school curricula to include learning outcomes on hazards and disasters. This was done in the USA because of fears of terrorist attacks (Ozmen 2006; O'Brien \& Read 2005) and in Japan after the country had experienced a number of earthquakes (Shaw et al. 2004). Chile and Thailand also responded by amending their curriculum to integrate the teaching of hazard awareness and disaster preparedness. None if any scholarly work has been done in South Africa to discuss how education can help in raising hazard awareness and disaster preparedness.

It is, however, important to note that South Africa, as a member of United Nations agencies, is affected by resolutions passed by those agencies. One such agency is UNESCO which, following the 2004 tsunami, recommended that countries should implement disaster risk reduction activities as people were eager to learn more about disaster preparedness (UNESCO 2007:25).

\section{Concern 3: To what extent are children in the South African school education system taught about hazards and disasters?}

The third concern of the study focused on whether learning outcomes in the South African national curriculum and school teaching included hazard and disaster knowledge and preparedness. A review of the National Curriculum Statements and related literature revealed that learners could go from Grade 1 to 6 without being taught about hazards and disasters prevalent in their areas or any dangers resulting for those risks. During data collection it was observed that

TABLE 2: Chart depicting educators' responses about the vulnerability of South African communities.

\begin{tabular}{|c|c|c|c|c|c|}
\hline \multirow[t]{2}{*}{ Vulnerability } & \multicolumn{5}{|c|}{ Province } \\
\hline & Gauteng & North-West & Kwa-Zulu Natal & Eastern Cape & Western Cape \\
\hline Vulnerable & 30 & 30 & 29 & 30 & 29 \\
\hline Not vulnerable & 0 & 0 & 1 & 0 & 1 \\
\hline
\end{tabular}

Source: Rambau, S.T., 2011, 'Educational perspectives on learner awareness of hazards and disasters', PhD thesis, University of Pretoria, Pretoria, viewed 20 August 2012 , from http://upetd.up.ac. za/thesis/available/etd-10112011-121840 
in some schools teachers take the initiative by inviting fire fighters to discuss the dangers of fire. There is, however, a need for learners to be aware of many more hazards, such as epidemics and other health hazards. The curriculum implicitly includes hazard and disaster teaching in that it stipulates the teaching of some other concepts that can be used to teach about hazards and disasters. This realisation therefore leads to the argument that the national curriculum should explicitly stipulate what educators must teach learners.

In reviewed literature such as the UNESCO (2007) and ISDR reports (2008), Fothergill and Peek (2004), Paton and Johnston (2001) and Hosseini and Izadkhah (2006) there is strong evidence that the more prepared and knowledgeable a community is, the more resilient it becomes to disasters. In this article it is argued that education, in particular curriculum and teaching, is regarded as an important resource in making learners more aware of the hazards prevalent in their areas and even to be prepared when disasters occur. This argument is supported by Shaw et al., (2004), Shiwaku et al., (2007), Hosseini and Izadkhah (2006) and Ozmen (2006) who maintain that school education is important to ensure that learners respond appropriately when they are faced with a disastrous event.

It is also important to note that teaching learners about hazards and disaster preparedness is important not only for them but also for their communities, as illustrated by the following story about a young girl who saved many tourists' lives:

It is by now a well known story how a 10-year old British girl, Tilly Smith with her presence of mind and quick thinking saved about 100 lives on that day at one of the beach resorts in Phuket, Thailand. All she did was to alert people on the beach about the possible tsunami, when she saw a bubbling on the water, right on the edge and foam sizzling just like in the frying pan which she had leant in her geography class a few days before. (Rao 2007:8)

Scholars such as Wraga and Hlebowitsh (2003), Teodoro and Estrela (2010), Popkewitz (2010), Carl (2005), Kirk and MacDonald (2001), Chisholm (2005), Brooker and MacDonald (1999) and Jansen (1999) maintain that changes in society are the main drivers for curriculum development in a country. The South African case serves as an example of how political, economical, social and technological changes can drive curriculum change in a country. Every five years in the past decade or two has seen a move to revise the national curriculum, starting with the introduction of Outcomes-Based Education (OBE) in 1994 and going on to the introduction of Curriculum 2005 in 1999, the National Curriculum Statements (NCS) in 2004 and the Curriculum Assessment Policy Statements (CAPS) in 2009. The indication here is that curriculum revision can be linked to different political figureheads in the Department of Education. It should also be noted that the changes can have been brought about by lessons learnt and the resulting need to improve the education system.
As indicated in the background section, the South African National Curriculum Statements explicitly prescribe the teaching of hazards and disaster learning outcomes in Grade 7 Social Sciences but are silent regarding this topic in lower grades and in other learning areas. In discussing this, one has to note an argument by Smith and Lovat (2003) that there is a hidden and explicit curriculum which imply that although not listed explicitly as learning outcomes, hazards and disasters can be regarded as hidden in other learning outcomes such as those related to the environment, water, forestation, etc.

From the empirical data collection point of view, the responses by interview participants provided a way to determine whether hazards and disasters were integrated into school teaching. An analysis of responses revealed that disaster lecturers would like to see disaster risk reduction being taught to learners as early as possible, even before the onset of the formal school years. The curriculum coordinators concurred that hazards and disasters learning outcomes are already incorporated in Social Sciences and in other learning areas. All participants, support the notion of integrating hazards and disasters learning outcomes into the curriculum and classroom teaching. Some of the responses are as follows:

A female lecturer in disasters, from one of the Gauteng Universities commented that:

'Children should be taught about risks as early as possible before they start school, parents should be made aware to teach their children about disaster risks as early as possible and all teachers for the foundation phase should be made aware of the need to teach learners about disaster risk reduction.'

A female Curriculum Coordinator from the Northern Cape commented that:

'Disaster risk reduction is essential and should be included in the school curriculum. The integration should not only be done in Social Science but it should include all learning areas; Natural Science, Economics and Management, language, human sciences, Life Orientation as well as Mathematics.'

As for data collected through questionnaires, educators were asked two questions to discover whether the South African basic education system includes hazard and disaster learning outcomes in the curriculum and classroom teaching. The first question asked whether hazard and disaster education should be included in the national curriculum. Almost all the questionnaire respondents (98\%) indicated that hazard and disaster learning outcomes should be integrated in the national curriculum whilst $2 \%$ commented that it should not be included. These respondents were then asked to explain why it should not be included and the response was: 'Learners should not be bombarded by dooms issues but by possibilities that life affords to them.'

The second question was aimed at determining whether educators themselves were teaching learners about hazards and disasters. The chart below depicts the responses to this question. 
The chart above reveals that $83 \%$ of the respondents in Gauteng, 80\% in North West, 87\% in KwaZulu-Natal, 77\% in the Eastern Cape and 70\% in the Western Cape responded that learners were taught about hazards and disasters in their schools. An average of $21 \%$ responded that hazard and disaster learning content was not included in classroom teaching. The reasons why an average of $79 \%$ of the respondents reported that teachers were actually teaching about hazards and disasters in the classroom can be found in the comments by these educators (given below), which provide useful insights:

A Grade 5 male educator from KwaZulu Natal commented that:

'The current Natural Science curriculum is not dealing with disasters per se but one of our initiatives, Earth and Beyond Campaign, focuses on pollution and global warming, effects of volcanoes and deforestation where some of teachers have integrated the teaching of disasters.'

A Khayelitsha male educator respondent from the Western Cape who has been teaching for 29 years commented that:

'We are dealing with hazards and disasters in Natural Sciences and Economic and Management Sciences learning areas even though it is not part of the curriculum. We do this because learners experience fires and heavy rains in our area and we want them to be protected.'

The comments show that educators regard teaching about minor matters such as pollution and deforestation as teaching about hazards and disasters, hence their high response rate (79\%) on the second question. This response rate does not mean that they are currently teaching learners about disaster preparedness and hazard awareness in its entirety. It simply means that they are aware of the need to teach hazard awareness and disaster preparedness and that where they can, they include some concepts related to disaster education.

It should also be noted that some scholars report that the new curriculum policy provisions for classroom practice are not adequately translated in South Africa and that educators are therefore still using the old system of teaching. This can also explain why $79 \%$ of the respondents indicated that they were teaching hazards and disasters in their classrooms.

Pudi (2006) noted that teachers only teach what is prescribed by paraphrasing a comment made by one of the educator respondents in his study. The respondent stated that:

'It is not necessary for the teacher to teach beyond the present curricular as this will breed confusion. Teachers are already confused with the many changes that are taking place in education especially when they have to change.'
This comment is a good indication of educators' frustrations about the changes taking place in the education system.

In summary, the finding regarding the first concern of the study is that South Africa has a prevalence of disasters such as floods, fires, droughts, epidemics, storms, accidents (transport and industrial) and that it experiences social conflicts such as xenophobic attacks. These disasters result in loss of life and property even though they are not on the scale of some of the tsunamis, earthquakes and landslides that have affected other parts of the world. The implication of this finding is that disaster education in South Africa should focus on the hazards and disasters that are prevalent in this country and that learners who live or go to school in informal settlements should be given more attention as they are the most affected when disasters occur. This has implications for curriculum and learning programme development which will be discussed in more detail below.

The finding regarding the second concern of this study is that areas inhabited by poor people in South Africa, such as informal settlements, are especially vulnerable to disasters. It should be noted here that the South African population as a whole is vulnerable to disasters even though it is emphasised that the poor are most severely affected.

Dekens (2008) argue that indigenous and local knowledge, if combined with external, scientific knowledge, can enable implementing organisations to create innovative and sustainable solutions to reduce disaster risks and is important in building community confidence as communities themselves need to be convinced that some of their local knowledge and practices are relevant to disaster preparedness. According to a report by UNESCO (2007), education for disaster preparedness is a never-ending process that requires constant collaboration efforts by all parties concerned. Hartnady (2010) argues that sustainable development agencies must engage with education authorities to promote hazard awareness and community preparedness by influencing the development of new curricula, textbooks and teacher training in both primary and secondary schools.

The statement that informal settlements are vulnerable areas was supported by a literature review, interview respondents and comments from educators who indicated that some of the learners in their schools live in shacks. It is therefore important for the drivers of the current education system to consider amending the curriculum for schools located in vulnerable communities by adapting the contents to local needs and realities and by incorporating and fostering local knowledge and practices regarding hazard awareness and disaster preparedness.

TABLE 3: Questionnaire responses by educators on whether hazard and disaster learning outcomes are included in classroom teaching.

\begin{tabular}{|c|c|c|c|c|c|}
\hline \multirow[t]{2}{*}{ Inclusion } & \multicolumn{5}{|c|}{ Province } \\
\hline & Gauteng & North-West & Kwa-Zulu Natal & Eastern Cape & Western Cape \\
\hline It is included & 25 & 24 & 26 & 23 & 21 \\
\hline It is not included & 5 & 6 & 4 & 7 & 9 \\
\hline
\end{tabular}

Source: Rambau, S.T., 2011, 'Educational perspectives on learner awareness of hazards and disasters', PhD thesis, University of Pretoria, Pretoria, viewed 20 August 2012, from http://upetd.up.ac. za/thesis/available/etd-10112011-121840 
Regarding the third concern of the study, it was found that hazard and disaster education is essential for learners. This was evidenced by responses from the interview participants indicating that the majority were teaching disaster preparedness in their classrooms. There is a need to increase the awareness of teachers of the importance of teaching about hazards and disasters, especially those who are not teaching it and those who teach it but do not focus specifically on hazards and disasters that are prevalent in South Africa.

The national curriculum as a guide to what teachers should include in their learning programmes is critical in enhancing learners' hazard awareness and disaster preparedness. The curriculum should therefore be reviewed so that hazard and disaster learning outcomes can be integrated into a learning area such as life orientation, to ensure that all learners at all stages of their learning development will be prepared and resilient in the face of disasters. This therefore gives rise to the need for developing learning programmes on hazard awareness and disaster preparedness for grades other than Grade 7 and learning areas other than Social Sciences. It is against this background that the Department of Basic Education, Department of Higher Education and Training, universities and Disaster Management Institutes should collaborate in developing appropriate learning programmes at various levels, thereby ensuring disaster risk reduction through learners being made aware of hazards and prepared for disasters.

Suggested areas for further research include determining the impact of integrating hazard and disaster topics in the school learning programmes, the role of local and indigenous knowledge in disaster preparedness, and investigating the effectiveness of customising the school curriculum to local needs and context.

\section{Conclusion}

According to the sampled participants and literature consulted, the hazards and disasters prevalent in South Africa include floods, fires, droughts, accidents, epidemics and storms. Although every citizen in the country is vulnerable to such disasters, poor communities, especially those in informal settlements, are affected most severely by these disasters. The research participants indicated that education is important to ensure that learners and, through them, the general population are properly prepared for disasters. Although the questionnaire respondents maintained that hazard awareness and disaster preparedness are taught in schools, the interview participants stressed that disaster education should start in the early learning phases. Based on the data collected through literature, questionnaire respondents and interview participants, it would be safe to say that education is critical in ensuring that learners are aware of hazards and prepared for disasters.

\section{Acknowledgements Competing interests}

The authors declare that they have no financial or personal relationship(s) which may have inappropriately influenced them in writing this article.

\section{Authors' contributions}

L.D. (University of Pretoria) was the supervisor for the study. W.F. (University of Pretoria) was the Co-Supervisor of the Study. T.S. (University of Pretoria) was responsible for project design, data collection, report writing and writing the manuscript.

\section{References}

Alexander, D., 1997, 'The study of natural disasters, 1977-1997: Some reflections on a changing field of knowledge', Disasters 21(4), 284-304.

Arunotai, N., 2008, 'Saved by an old legend and a keen observation: The case of Moken Sea Nomads in Thailand', in ISDR, Indigenous knowledge for disaster risk reduction: Good practices and lessons learned from experiences in the Asia-Pacific region, pp. 73-78, viewed 13 May 2011, from http://www.unisdr.org/files/761 region, pp. $73-78$, viewed 13 .
education-good-practices.pdf

Atwater, B., Cisternas, M., Bourgeois, J., Dudley, W., Hendley, J. \& Stauffer, P., 2005 Surviving a tsunami: Lessons from Chile, Hawaii, and Japan, Circular 1187, US Geological Survey, Reston.

Arredondo, D.E. \& Rucinski T.T., 1998, 'Principal perceptions and beliefs about integrated curriculum use', Journal of Educational Administration 36(3), 286-296.

Beckford, C., Jacobs, C., Williams, N. \& Nahdee, R., 2010, 'Aboriginal environmental wisdom, stewardship and sustainability: Lessons from Walpole First Nations, Ontario, Canada', Journal of Environmental Education 41(4), 239-248.

Berriman, M., 2004, 'The genomes of eukaryotic pathogens', South African Journal of Science 100(9/10), 452-458.

Bollig, M., \& Schulte, A., 1999, 'Environmental change and pastoral perceptions: Degradation and indigenous knowledge in two African pastoral communities', Human Ecology 27(3), 493-514.

Boshoff, H., Barry III, C. \& Mizrahi, V., 2004, 'Mutational dynamics in mycobacterium tubercolosis: Implications for the evolution of drug resistance', South African Journal of Science 100(9), 471-473.

Brooker, R. \& Macdonald, D., 1999, 'Did we hear you? Issues of student voice in a curriculum innovation', Journal of Curriculum Studies 31(1), 83-97.

Bull-Kamanga, L., Diagne, K., Lavell, A., Leon, E., Lerise, F., MacGregor, H., et al., 2003 , 'From everyday hazards to disasters: The accumulation of risk in urban areas', Environment and Urbanisation 15(1), 193-203.

Carl, A., 2005, 'The "voice of the teacher" in curriculum development: a voice crying in the wilderness?', South African Journal of Education 25(4), 223-228.

Chisholm, L., 2005, 'The making of South Africa's National Curriculum Statements', Journal of Curriculum Studies 37(2), 197-208.

Dekens, J., 2008, 'Local knowledge on flood preparedness: Examples from Nepa and Pakistan', in ISDR, Indigenous knowledge for disaster risk reduction: Good practices and lessons learned from experiences in the Asia-Pacific region, pp. 35-40, viewed 13 May 2011, from http://www.unisdr.org/files/761_educationgood-practices.pdf

Fothergill, A. \& Peek, L.A., 2004, 'Poverty and disasters in the United States: A review of recent sociological findings', Natural Hazards 32, 89-105.

Frost-Killian, S., 2008, 'Geohazards: The risks beneath our feet', Quest 4(2), 28-33.

Gaillard, J., 2007, 'Resilience of traditional societies in facing natural hazards', Disaster Prevention and Management 16(4), 522-544.

Gey van Pittius, N., Sampson, S., Warren, L. \& Van Helden, P., 2005, 'Genome variation in Mycobacterium tuberculosis: Pathogens genomics', South African Journal of Science 100(10), 465-470.

Goetz, K., 2000, 'Perspectives on team teaching', EGallery 1(4), viewed 26 August 2011, from http://people.ucalgary.ca/ egallery/goetz.html

Gregson, S., Waddel, H. \& Chandiwana, S., 2001, 'School education and HIV Control in sub-Saharan Africa: From discord to harmony', Journal of International Development 13(4), 467-485.

Gupta, M. \& Sharma, A., 2006, 'Compound loss: The post-tsunami recovery experience of Indian Island communities', Disaster Prevention and Management 15(1), 67-78.

Hartnady, C., 2010, 'Scientist calls for earthquake awareness in Africa', Science in Africa, February, viewed 02 July 2011 from http://www.scienceinafrica. co.za/2010/february/earthquake_SA.htm 
Hassanain, M., 2006, 'Towards a design and operation of fire safe school facilities', Disaster Prevention and Management 15(5), 838-846.

Hellier, A., Newton, A \& Gaona, S., 1999, 'Use of indigenous knowledge for rapidly assessing trends in biodiversity: A case study from Chiapas, Mexico', Biodiversity and Conservation 8(7), 869-889.

Hemingway, J., 2004, 'The influence of genomics and the control of malaria and other vector-borne diseases', South African Journal of Science 100(9/10), 475-479.

Holloway, A. \& Roomaney, R., 2008, Weathering the storm: Participatory risk assessment for informal settlements Periperi Publications, Cape Town.

International Strategy for Disaster Reduction (ISDR), 2008, Indigenous knowledge for disaster risk reduction: Good practices and lessons learned from experiences in the Asia-Pacific region, 84 pp., viewed 26 August 2011, from http://www. preventionweb.net/files/3646_IndigenousKnowledgeDRR.pdf

International Strategy for Disaster Reduction (ISDR), 2007, Towards a culture of prevention: Disaster risk reduction begins at school. Good practices and lessons learned, viewed 13 May 2011, from http://www.unisdr.org/files/761_educationgood-practices.pdf

Jansen, J.D., 1999, 'The school curriculum since apartheid: Intersections of politics and policy in the South African transition', Journal of Curriculum Studies 31(1), 57-67.

Kamara, J., 2006, Knowing nature: Indigenous knowledge helps in disaster management, Environmental Policy Implementation, UNEP.

Kana, B. \& Mizrahi, V., 2004, 'Molecular genetics of mycobacterium tuberculosis in relation to the discovery of novel drugs and vaccines', Tuberculosis 84(2), 63-75.

King, D., 2000, 'You're on your own: Community vulnerability and the need for awareness and education for predictable natural disasters', Journal of Contingencies and Crisis Management 8(4), 223-228.

Kirk, D. \& MacDonald, D., 2001, 'Teacher voice and ownership of curriculum', Journal of Curriculum Studies 33(5), 551-567.

Martin, D., 2005, 'Why it's so hard to combat AIDS', Quest 1(4), 11-13.

Meiklejohn, I. \& Sumner, P., 2005, 'Tsunamis: Your questions answered', Quest 1(3), 8-11.

Mgquba, S.K. \& Vogel, C., 2004, 'Living with environmental risks and change in Alexandra township', South African Geographical Journal 86(1), 30-38.

Morton, I., 1993, 'Teacher collaboration in secondary schools, National Centre for Research in Vocational Education', Centre Focus (2), December.

Mulegeta, G., Ayonghe, S., Daby, D., Dube, O., Gudyanga, F., Lucio, F. \& Durrheim, R., 2007, Natural and human-induced hazards and disasters in sub-Saharan Africa, ICSU Regional Office of Africa, Pretoria, viewed 17 August 2011, from http://www. fanrpan.org/documents/d00447/ICSUROA Hazards Disasters Aug 2011.pdf

Napier, M. \& Rubin, M., 2002, 'Managing environmental and disaster risks affecting informal settlements: Lessons in innovative practice from South African local authorities, CSIR, Pretoria.

National Disaster Management Centre (NDMC) - 2010', National education, training and research needs and resources analysis - Consolidated report, NDMC Pretoria, viewed 26 August 2011, from http://www.ndmc.gov.za/Documents/ NETaRNRAReport/tabid/295/ctl/ViewDocument/mid/678/ItemID/143/Default. aspx

National Disaster Management Framework (NDMC), 2005, Government Notice 654 of 2005, NMDC, Pretoria, viewed 04 October 2011 from http://www.ndmc.gov.za/ portals/0//WebDocuments/Guidelines/DM/downloads/SJ\%208\%20NDMF\%20 2005.pdf

Ogunniyi, M., 2007, 'Teachers' stances and practical arguments regarding a scienceindigenous knowledge curriculum part 2', International Journal of Science Education 29(10), 1189-1207.

Ozmen, F., 2006, 'The level of preparedness of the schools for disasters from the aspect of the school principals', Disaster Prevention and Management 15(3), 383-395

Paton, D. \& Johnston, D., 2001, 'Disasters and communities: Vulnerability, resilience and preparedness', Disaster Prevention and Management 10(4), 270-277.
Popkewitz, T.S., 2010, 'Curriculum study, curriculum history and curriculum theory: The reason of reason', Journal of Curriculum Studies 41(3), 301-319.

Pudi, T., 2006, 'From OBE to C2005 to RNCS: Are we still on track?' Africa Education Review 3(1-2), 100-112.

Rambau, S.T., 2011, 'Educational perspectives on learner awareness of hazards and disasters', PhD thesis, University of Pretoria, Pretoria, viewed 20 August 2012 from $\mathrm{http}$ ://upetd.up.ac.za/thesis/available/etd-10112011-121840

Rao, K., 2007, 'Imperatives for tsunami education', Current Science 93(1), 8-9.

Rautela, P., 2005, 'Indigenous technical knowledge inputs for effective disaster management in the fragile Himalayan ecosystem', Disaster Prevention and Management 14(2), 233-241.

Reich, J., 2006, 'Three psychological principles of resilience to natural disasters', Disaster Prevention and Management 15(5), 793-798.

Reid, P.M. \& Vogel, C., 2006, 'Living and responding to multiple stressors in South Africa: Glimpses from KwaZulu-Natal', Global Environmental Change 16(2), May, 195-206.

Robinson, B. \& Schaible, R.M., 1995, 'Collaborative teaching: Reaping the benefits', College Teaching 48(2), 57-59.

Rogan, J. \& Aldous, C., 2005, 'Relationship between constructs of theory of curriculum implementation', Journal of Research in Science Teaching 42(3), 313-336.

Rogan, J. \& Grayson, D., 2003, 'Towards a theory of curriculum implementation with particular reference to science education in developing countries', International Journal of Science Education 25(10), 1171-1204.

Sabetes-Wheeker, R., Devereux, S., Mitchell, T., Tanner, T, Davies, M., \& Leavy, J., 2008, 'Rural Disaster Risk-Poverty Interface, prepared for global assessment report on Disaster Risk Reduction', Institute of Development Studies, University of Sussex.

Shaluf, I., 2007, 'An overview of disasters', Disaster Prevention and Management 16(5), 687-703.

Shaw, R., Shiwaku, K., Kobayashi, H. \& Kobayashi, M., 2004, 'Linking experience, education, perception and earthquake preparedness', Disaster Prevention and Management 13(1), 33-49.

Shiwaku, K., Shaw, R., Kandel C., Shrestha S. \& Dixit, A., 2007, 'Future perspective of school disaster education in Nepal', Disaster Prevention and Management, 16(4), 576-587.

Schilderman, T., 2004, Adapting the traditional shelter for disaster mitigation and reconstruction: Experiences with community-based approaches', Building Research and Information 32(5), 414-426.

Sillitoe, P., 2000, 'Let them eat cake: Indigenous knowledge, science and the poorest of the poor', Anthropology today 16(6), 3-7.

Smith, D. \& Lovat, T., 2003, Curriculum: Action on reflection, 4th edn, Social Science Press, Australia.

Snively, G. \& Corsiglia, J., 2001, 'Discovering indigenous science: Implications for science education', Science Education 85, 6-34.

Tempelhoff, J., Van Niekerk, D., Van Eeden, E., Gouws, I., Botha, K. \& Wurige, R., 2009 'The December 2004 - January 2005 floods in the Garden Route region of the Southern Cape', Jàmbá: Journal of Disaster Risk Studies 2(2), 93-112.

Teodoro, A. \& Estrela, E., 2010, 'Curriculum policies in Portugal (1995-2007): Globa agendas and regional and national reconfigurations', Journal of Curriculum Studies 42(5), 621-647.

United Nations Educational, Scientific and Cultural Organization (UNESCO), 2007, Natural disaster preparedness and education for sustainable development viewed 26 August 2011, from http://www2.unescobkk.org/elib/publications/103/ disaster.pdf

Vandeyar, S. \& Killen, R., 2007, 'Educators' conception and practice of classroom assessment in post-apartheid South Africa', South African Journal of Education 27(1), 101-115.

Weltz, T., Hosegood, V., Jaffar, S., Batzing-Feigenbaum, J., Herbst, K. \& Newell, M. 2007, 'Continued very high prevalence of HIV infection in rural KwaZulu-Natal, South Africa: A population-based longitudinal study', AIDS 21(11), 1467-1472.

Wraga, W.G. \& Hlebowitsh, P.S., 2003, 'Toward a renaissance in curriculum theory and development in the USA', Journal of Curriculum Studies 35(4), 425-437. 